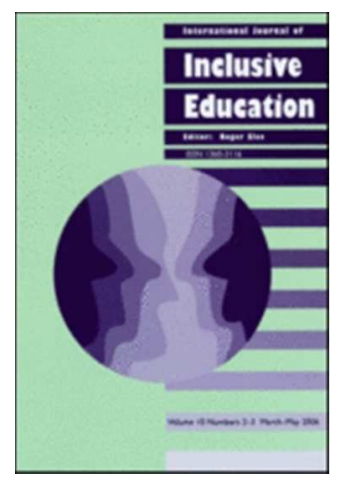

\title{
'To what extent have learners with severe, profound and multiple learning difficulties been excluded from the policy and practice of inclusive education?'
}

\begin{tabular}{|r|l|}
\hline Journal: & International Journal of Inclusive Education \\
\hline Manuscript ID & TIED-2017-0251.R3 \\
\hline Manuscript Type: & Original Article \\
\hline Keywords: & $\begin{array}{l}\text { Special Education, Inclusive Education, Special Education Needs, Education } \\
\text { Policy, severe learning difficulties, profound and multiple learning } \\
\text { difficulties }\end{array}$ \\
\hline
\end{tabular}

\section{SCHOLARONE}

Manuscripts 


\title{
'To what extent have learners with severe, profound and multiple learning difficulties been excluded from the policy and practice of inclusive education?'
}

\author{
Key Words: Special Education; Inclusive Education; Special Educational Needs; \\ Education Policy; Severe Learning Difficulties; Profound and Multiple Learning \\ Difficulties
}

\begin{abstract}
The article is a position paper on inclusive practice in education with respect to students with severe or profound and multiple learning difficulties (sld/pmld). It asks if children and young people with sld/pmld have been excluded from the policy and the practice of inclusive education. A review of the literature found that there is a research gap around inclusive education for learners with sld/pmld, and a review of historical and current practices indicated that this group of learners has indeed been excluded from both the policy and practice of inclusion in the United Kingdom with the use of curricula based on a mainstream linear and academic model reinforcing this exclusion. The study makes a theoretical and practical contribution to the continuing debate about inclusive education and will be of interest to teachers, parents, policy-makers and the learners themselves
\end{abstract}




\section{Introduction}

The article is a position paper on inclusive education in the UK and in some other countries with respect to learners with severe or profound and multiple learning difficulties (sld/pmld) and will explore Carpenter et al's (2015) suggestion that initiatives to include all in educational settings have failed to include those with sld/pmld. By analysing recent policy and related literature the author will show that this sizable group of learners has indeed been very largely excluded from the policy and practice of inclusive education and overlooked in debates around inclusion, with the use of curricula based on linear and academic models reinforcing their exclusion. The author will explore what Hodkinson (2012) refers to as the 'long history of the theory and praxis of inclusion' (p. 4) and in particular the consequences of 'the clash between ideality and practicality' (p.7), with a view to uncovering whether this clash has contributed to the exclusion of learners with sld/pmld from policy and practice. The author will also ask to what extent ambiguities around the meaning of inclusion (Booth et al., 2006; Lacey and Scull, 2015) are an inevitable result of the complexities of the issues involved or 'ideological screens' (Walton, 2016, p 91) which have allowed learners with sld/pmld to be overlooked, a question raised by Martin Murray writing about the English education system in the Letters Page of The Independent newspaper in April 2015: 'What do words such as excellence, inclusion and progression mean anymore? The erosion of meaning is corrosive and deliberate'. 


\section{Severe or profound and multiple learning difficulties (sld/pmld)}

In an educational context in the United Kingdom, the terms 'severe learning difficulties' (sld) and 'profound and multiple learning difficulties' (pmld) refer to two distinct groups with defining learning characteristics (Author, 2017), although there is very often overlap between the two, and the terms 'sld' and 'pmld' are sometimes combined as 'sld/pmld', which will be the case in this article. It has been estimated (Dept. for Education, 2015) that there are currently more than 40,000 children and young people with sld/pmld in the UK.

There has been little updating of the definitions of 'sld' and 'pmld' since the UK Department for Education in 2012 (Lacey and Scull, 2015) which put forward the following:

\footnotetext{
'Pupils with severe learning difficulties (SLD) have significant intellectual or cognitive impairments. This has a major effect on their ability to participate in the school curriculum without support. They may also have difficulties in mobility and coordination, communication and perception and the acquisition of self-help skills. Pupils with SLDs will need support in all areas of the curriculum. They may also require teaching of self-help, independence and social skills. Some pupils may use sign and symbols but most will be able to hold simple conversations. Their attainments may be within the upper P scale range (P4-P8) for much of their school careers'. (DfE, 2012)
} 
'Pupils with profound and multiple learning difficulties have complex learning needs. In addition to very severe learning difficulties, pupils have other significant difficulties such as physical disabilities, sensory impairment or a severe medical condition. Pupils require a high level of adult support, both for their learning needs and also for their personal care. They are likely to need sensory stimulation and a curriculum broken down into very small steps. Some pupils communicate by gesture, eye pointing or symbols, others by very simple language. Their attainments are likely to remain in the early P-scale range (P1P4) throughout their school careers.' (DfE, 2012).

For clarification, the $\mathrm{P}$ (performance) scales ${ }^{1}$ are an 8 -point assessment tool which has been in wide use in the UK since the late 1990's. The P scales sit below the UK National Curriculum and report the attainment of pupils with special educational needs who are not working at the standard of mainstream statutory assessments. A learner with profound and multiple learning difficulties (pmld) for example might be assessed at working at P3 (ii) in some areas, which is defined as follows:

'P3 (ii): Pupils use emerging conventional communication. They greet known people and may initiate interactions and activities [for example, prompting another person to join in with an interactive sequence]. They can remember learned responses over increasing periods of time and may anticipate known events [for example, pre-empting sounds or actions in familiar poems]. They may respond to options and choices with actions or gestures [for example, by

\footnotetext{
${ }^{1}$ A review of assessment for pupils working below the standard of national curriculum tests in the UK carried out by Diane Rochford at the request of the Minister of State for Schools and published in October 2016 has recommended that The P Scales be gradually phased out.
} 
nodding or shaking their heads]. They actively explore objects and events for more extended periods [for example, turning the pages in a book shared with another person]. They apply potential solutions systematically to problems [for example, bringing an object to an adult in order to request a new activity]'.

(QCA, 2009; 8). 


\section{Historical Background}

\section{Late $19^{\text {th }}$ and early $20^{\text {th }}$ century}

A lack of clarity about what inclusion means in practice for learners with sld/pmld is not a new issue. From the second half of the $19^{\text {th }}$ century there was very little in the way of education for people with learning difficulties, and successive legislation in the UK (Wearmouth, 2011) such as The Lunacy and County Asylums Acts 1845 (8 \& 9 Vict., c. 100), The Idiots Acts 1886 (49 Vict.c.25) and The Lunacy Act 1890 (53 Vict, c5) meant that there was effectively no educational provision at all for those we now describe as having sld/pmld and who survived infancy.

The more explicit exclusion of children and young people with high levels of need from educational settings in the UK was established for 70 years (Stewart, 2015) by the 1899 Elementary Education (Defective and Epileptic Children) Act (56 / 57 Vict. C42). Only children 'not being imbecile' (p. 11) would receive education and decisions of selection would be made by medical practitioners. This was also the period which saw the building of large asylums (Frogley and Welch, 1993), and although there was at least a scientific interest in the education of the asylum population through alternative forms of care such as those created by James Matthews at Bethlem, or the York Retreat (Jay, 2016) as well as significant vocational educational initiatives in the US (Wehmeyer, 2013), those we describe now as having sld/pmld were routinely institutionalised or kept at home. Subsequently, the legislative division in the UK between those who could and couldn't be educated was reinforced by the Mental Deficiency Act (1913) and the Mental Treatment Act (1930). 


\section{Second half of $20^{\text {th }}$ century}

The introduction of mass public education in the UK, and the increase in the age limit for compulsory schooling from 10 in 1880 to 15 by 1947 was arguably the first point where the 'problem of inclusion' (Dahl, 1991 and Warnock, 2005) became an issue. Public education on this scale was never designed with disabled learners in mind (Gunnpórsdóttir, 2014), let alone those with the severest difficulties, and all subsequent attempts to include those children who did not fit in to regular schools are marked by this ‘inherent technical paradigm' (Gunnpórsdóttir, 2014: p. 26) with two contrasting forces at work (Armstrong, Armstrong and Spandagou, 2010): the challenge of 'transforming ideal into practice' (Allan, 2013) by extending educational opportunities to all, and the management of children who did not fit within a mainstream system. The author suggests that this was to become a defining issue in the policy and practice of inclusive education for those with severe or multiple difficulties.

The 1944 Education Act deemed that some children were nevertheless uneducable and became the responsibility of the Health Authorities, and from this point on special education gained a logic of its own (Armstrong, Armstrong and Spandagou, 2010). Between 1947 and 1955 the number of children in the UK in what were often known as 'hospital schools' nearly doubled and special education came to be seen as a depository for those who fell outside the norm (Walton, 2016). The place of instruction rather than the instruction itself (Kauffman, Ward and Badar, 2016) would become a central issue in future debate (Wehmeyer, 2006), and this led to a gradual shift towards an inclusive mind set, nurtured by the United Nations Universal Declaration (1948) which affirmed inclusion in education as a human right. At the same time, there were a number of significant conceptual shifts in health care in the UK: segregated institutions became 
subject to criticism, and this marked the beginning of the end for the large asylums (Frogley and Welch, 1993).

Public sector policy in education also began to reflect this shift (Author, 2013 and Blatter, Blaettler and Schmid S, 2015), and the Education (Handicapped Children) Act (1970) stipulated that all children with disabilities were entitled to educational provision and became the responsibility of the Local Education Authority. 32000 children were transferred from Health to Education systems, effectively the cohort with severe learning difficulties who were excluded by the 1944 Act (Lacey et al, 2015), and the issue of including those with more complex needs in mainstream schools returned.

The Warnock report of 1975 came close to making a clear statement in favour of full inclusion but only actually stipulated that 'wherever possible' (p. 122), children with special needs should be educated in ordinary schools. Despite this, Walton (2016) reminds us that from about 1980 the word 'inclusion' in the UK and other contexts has been routinely applied to educating all - irrespective of level of need - in the mainstream classroom (Walton, ibid), with the moral rightness of full inclusion in mainstream settings treated as axiomatic. This reflects both Wehmeyer's second generation of inclusion with its focus on 'instructional practices' (p. 323) and third generation of inclusion with its focus on progress within a general education curriculum. The 1981 Education Act enacted many of Warnock's recommendations though Runswick-Cole (2011) calls this a naive approach to inclusion which encouraged no more than the physical placement of children with special needs in mainstream classrooms. In some ways a logical extension of the 1981 Education Act, the 1989 UK National Curriculum introduced a curriculum for all, though it quickly 
became apparent (Byers and Lawson, 2015) that it did not cater for learners with sld/pmld.

Nevertheless, the next 20 years marked the high point in attempts to include all in educational settings, with some bold experiments in what was often called 'integration' (Jordan and Goodey, 2002), some instances of children with sld/pmld being bussed into mainstream schools (Byers and Lawson, 2015), and in some areas a 'dogmatic attempt to discontinue special schools' (Allan and Brown, 2001, p.200). The London Borough of Newham was however the only education authority in the UK to accept fully the principle of inclusion for children 'whatever their special need' (Newham Council, 1995), yet despite determined efforts to close all the special schools in the borough from 1984 onwards, a school over two sites catering for pupils with sld /pmld and autism has survived, and mainstream secondary schools in the borough provide for pupils with higher level of need in resourced provision such as separate units or classrooms.

\author{
Alongside these policy shifts in the UK, international conventions (Gunnpórsdóttir, \\ 2014) appeared to continue to support the idea of full inclusion in mainstream settings \\ for everybody irrespective of level of need, though Article 23 of the 1990 UNESCO \\ Convention of the Rights of the Child while affirming the rights of physically disabled \\ children to integration, qualified that by saying that these rights should be dependent on \\ available resources and appropriate to the condition of the child (Wearmouth, 2011). \\ The 1994 UNESCO Salamanca World Congress statement on Inclusive Education \\ which was signed by 92 governments, appeared to present less of a compromise, though \\ it is policy, not law (Walton, 2016) and its statements are hardly unambiguous in their


support for full inclusion: 'Regular schools with an inclusive orientation are the most $\underline{\text { effective means of combating discriminatory attitudes...countries should concentrate }}$ their efforts on the development of inclusive schools' (p. 1) (author's underscore). Arguably then, schools without 'an inclusive orientation' were off the hook, and as long as countries were simply making an effort then progress was apparently being made towards including all. Gunnpórsdóttir (2014) shows that the UNESCO definition of inclusive education is policy and process-related as it simply defines a desirable aim for nations of the world to work towards.

\section{The $21^{\text {st }}$ Century}

By the beginning of the $21^{\text {st }}$ century, the word 'inclusion' on its own could legitimately refer to different aspects of school or society (Gunnpórsdóttir, 2014). For some as we have seen inclusion is simply a matter of place, echoing Warnock's (1978) original definition of 'locational integration' and with Kearney (2011) insisting that a principle of inclusion is simply that all children belong at their local school. Others see inclusion in terms of equitable outcomes (Ayers et al, 2012) or social opportunities (McRuer, 2011) and in particular the key importance of overcoming the barriers to those social opportunities created by a culture of 'compulsory able-bodied-ness' (McRuer, 2011, p. 591). Possibly unsurprisingly then, the definition of 'inclusive education' also now varies significantly between and within cultures and educational systems (Dyson, 1999; Ainscow, 2005). The Netherlands for example has a 2-track orientated system with separate special and mainstream schools, Australia has a one-track system and tries to avoid any form of segregation and the UK and the USA has developed over the last 20 
years or so 'a continuum of provision' (Hornby, 2015; Norwich, 2008) including but not limited to:

- Full inclusion of pupils with sld/pmld in mainstream classes

- Partial inclusion of pupils with sld/pmld of in mainstream classes with some dedicated provision in special units.

- Mainstream schools with onsite resourced provision for pupils with sld/pmld

- Special schools next door to or on the same campus as mainstream schools.

- Special schools with close links to local mainstream schools.

- Special schools with no links to local mainstream schools.

- Residential settings

Policy statements however in favour of 'full' inclusion continued in the UK, though most still fell short of addressing the unique challenge of actually including those with sld/pmld in all aspects of school life. The 1995 Disability Discrimination Act required all schools to make 'reasonable adjustments' for pupils with disabilities and to draw up plans to increase accessibility, and the 2001 Special Educational Needs and Disability (SEND) Code of Practice (DfES, 2001) required all teachers, to identify and meet the needs of pupils labelled as having SEND within mainstream schools. This requirement however was compromised by the fact that there was little or no training available (Hodkinson and Vickerman, 2009), and no formal Special Educational Needs (SEN) initial teacher training (Carter, 2015).

More recent official policy on inclusion in the UK can be said to have shown an acknowledgement at least that attempts to include all may have failed (Carpenter, 
2015), and by 2005 Warnock herself had retracted significantly calling inclusion simply 'a common enterprise of learning, rather than being necessarily under the same roof' (Warnock, 2005, p. 39). The then Department for Education and Skills produced its strategy for special educational needs, 'Removing Barriers to Achievement' (2004) which rejected more radical versions of inclusive education and reaffirmed the role of special schools, and in 2006 Ofsted's 'Does it matter where pupils are taught?' noted that effective provision could be distributed equally between mainstream and special schools.

However, ambiguity around inclusion and its meaning still exists (Robertson, 2015). The UK Coalition Government's Green Paper 'Support and Aspiration' (2011) made a commitment to 'remove the bias towards inclusive education' (p. 5), but in the Special Educational Needs and Disability Code of Practice (2015), which is statutory guidance, there is a call for 'a focus of inclusive practice' (page 20), a phrase which appears 7 more times in the document. Robertson (2015) points out however that the 'imperative for inclusion' (page 28) is itself trumped in the document by the statement that parents of learners with Education Health and Care (EHC) plans can choose either a mainstream or special school placement, and that learners can be 'educated effectively in a range of mainstream or special settings' (page 28). From a recent international perspective however, the 2015 Lisbon Educational Equity Statement seems to reinforce the original UNESCO standpoint by 'promoting the development of inclusive schools'.

The problematization of inclusion then (Pather, 2007), and in some cases uncritical discussion and ill-informed reflection (Howes, Davis and Fox, 2009), continues to 
reinforce the exclusion of pupils with severe, profound and multiple learning difficulties from educational policy and practice into the $21^{\text {st }}$ century. This has had a particular impact in the areas of curriculum and in the more recent framing of 'autonomy' as a desirably educational outcome for all.

\section{Curriculum}

The UK Department for Education has referred to severe learning difficulties as having a major effect on the learner's ability to participate without support in the school curriculum (DfE, 2011) and more recently to children with both sld and pmld 'needing support in all areas of the curriculum' (DfE, 2015), implying that this group of learners can be included in a mainstream or 'general' curriculum and reflecting Wehmeyer's (2006) 'third generation' (p. 323) of inclusion which seeks to ensure that students with severe disabilities progress within a general education curriculum. Hart et al, (2007) and Gillard (2009) both also assert that teaching a different, separate, specifically designed curriculum to children with special educational needs, rather than teaching the same curriculum in a differentiated way, would be marking such children out as fundamentally other, thereby labelling and possibly stigmatising such children. Indeed, much of the debate in academic journals in the past decade (Ware, 2014) around the education of children with sld/pmld has been based on the assumption that the ideal to be aimed for is access to the same curriculum for all children, using broadly similar pedagogical strategies, differentiated only on the basis of the individual learner's responses. 
Similarly, the assumption in some key recent UK Policy documents such as Valuing People (2001), Aiming High for Disabled Children (2007), Valuing People Now (2010) and the Special Educational Needs and Disability Code of Practice (2015) is that 'with the right help and support' ('Valuing People', p. 24) all people with learning difficulties including those with sld/pmld can be effectively included in mainstream or 'general' curricula. Hudson, Browder, \& Wood, (2013) reinforce this belief in their review of the literature on academic learning in general education settings for students with 'moderate and severe learning disability' (p. 17) concluding that there was evidence that certain instructional practices did enable students with severe intellectual impairment to access the same curriculum as their non-disabled peers.

However, one of Hudson, Browder, \& Wood's (2013) sub indicators of success was met 'if participants learned a minimum of five skills (e.g. at least five different sight words, at least five different vocabulary definitions' (p. 19) and 'one student learned definitions for states of matter (p. 25)'. This suggests that the students surveyed would not have been defined as having severe or profound multiple learning difficulties according to any of the definitions currently in use in the UK context and earlier in this article, and is an example of the tendency in these same recent UK policy documents (Author, 2017) to conflate all levels of disability and to approach the question of pedagogy from an overarching special educational needs perspective rather than looking at those with sld/pmld as the unique and complex learners that they are. This undermines the cause of those with the highest level of need as Author (2017), Rochford (2016) and Imray and Hinchcliffe (2014), all show that young people with severe or profound learning difficulties are not likely to succeed in any significant way in the UK National 
Curriculum, or in any linear, mainstream curriculum model designed for neuro-typical conventionally developing learners, because they do not learn in linear or typical ways.

To exclude even further those with highest levels of need, governments in many countries, including the UK (Hornby, 2015), have begun to focus on measurable academic achievement within a National Curriculum which was not designed for those with sld/pmld. For Gunnpórsdóttir, (2014) this is a tension between 'striving for effectiveness, on the one hand, and pressure for inclusiveness, on the other' (p. 38), with accountability undermining inclusive education (Blower, 2015). This has meant (Lacey, 2001) that within a result driven culture, children who required a high level of teacher support or resources as well as personalised curricula, along with those who fail to meet behavioural norms, became unattractive clientele for schools striving to improve standards (Runswick-Cole, 2011; Robertson, 2015), and has led (Walton, 2016) to some learners being excluded in the drive to meet indicators of effectiveness.

\begin{abstract}
Autonomy
Valuing People (2001), Aiming High for Disabled Children (2007), Valuing People Now (2010) and the Special Educational Needs and Disability Code of Practice (2015) also make it clear that autonomy is axiomatic in any discussion about life outcomes for people with disabilities, though without ever discussing in any depth what autonomy means for those with sld / pmld. 'Valuing People' (2001) for example, is very clear in its aims to 'provide new opportunities for children and adults with learning disabilities and their families to live full and independent lives as part of their local communities.' (p. 2) and going on to say that 'the starting presumption should be one of independence, rather
\end{abstract}


than dependence' (p. 23). 'Aiming High for Disabled Children' (2007) echoes these sentiments: 'support at transition to adulthood is vital to enable disabled young people to gain independence' (3.55, p. 40). Autonomy - expressed also as 'independence’ (p. 122. 7.37) is also central to the SENCoP (2015) which sets out clearly to 'promote independence and self-advocacy for children' (p. 32. 2.8), 'help them gain independence and prepare for adult life' (p. 120. 8), 'promote greater independence and learn important life skills' (p. 124. 8.7) and 'achieve independence in all aspects of life' (p. 295). Independence is also seen as a pre-requisite to achieving 'self-esteem' (p. 123. 8.2) implying that any forms of dependency are seen as inherently undesirable.

However, the concept of adult autonomy, Taylor (2014) notes, is 'a fantasy' (p. 260). We are, Kittay reminds us, 'selves-in-relation' (p 54) and with respect to people with sld/pmld, issues of autonomy are particularly salient both for the carer and for the cared for, though both are 'stigmatised by dependency' (p. 51). To be the parent or carer of someone with sld/pmld can often be isolating, frustrating and economically challenging. Dignity however can also be found 'in relations of dependency' (Nussbaum, 2006 p. 218) but not as long as policy prioritises independence for all irrespective of level of need

All four policy documents discussed here make it clear that autonomy for people with all learning difficulties also equates to employment. 'Aiming High for Disabled Children' (2007) calls employment a major aspiration for people with learning disabilities, and 'Valuing People Now' talks about the 'presumption of employability' (p. 88 ), and assures us that for people with more complex needs the aim is the same as for everyone: 'inclusion and participation in all areas of community life, including living 
independently and having paid work'. (p. 34). 'Valuing People Now (2010) is precise that people with learning difficulties 'have a role to play as contributors (...) and should be supported to work, pay taxes, vote, do jury duty, have children, (p. 33), which they note will benefit society as a whole. Armstrong, Armstrong and Spandagou (2010) see this insistence on employability as a by-product of the neo-liberal introduction of production for profit as a key principal not only of economic life but also within the public sector and education in particular, what McRuer (2009) calls 'neoliberalism, trickle-down economics, the Washington consensus' (p. 591). The bar then for those with sld/pmld is set very high, yet a very significant proportion of all people with learning difficulties have little or no prospect of performing basic work skills in a knowledge economy (Shakespeare, 2014) let alone those with the highest levels of need.

With the meanings of 'inclusion' and 'inclusive education' still hotly debated and subject to conditions and ambiguities (Walton, 2016) and key Government policy documents conflating all levels of disability and insisting on an unspecified 'autonomy' for all, it is not surprising to find that learners with severe, profound and multiple learning difficulties continue to be excluded from policy and debate. To what extent though do attitudes and understandings amongst researchers and practitioners in the UK and elsewhere reflected these issues? 


\title{
Attitudes and Understandings of Inclusion with respect to learners with
}

\begin{abstract}
sld/pmld
The values, beliefs and perspectives of society (Wearmouth, 2011) as well as national or regional circumstances (Ainscow, 2005) have impacted on the understanding of inclusion. The word itself is infected with 'extant ideological ghosts' (Hodkinson, 2012, p.3) and certainly in the UK there has for a long time been considerable confusion among researchers and teachers (Allan, 2013) as to what inclusion actually means and who it is for (Armstrong, Armstrong \& Spandagou, 2010). Shuttleworth (2013) points out that researchers and practitioners who appear in favour of 'full' inclusion often have 'exclusion clauses' pinned to their inclusion arguments.
\end{abstract}

This fluidity of meaning has led to often heated debate which has made it difficult to move practice forward (Florian, 2007). Lacey (2011, p. 243) calls this a 'with us or against us' model with some people feeling that a child's needs can only be met at one end of the inclusion spectrum or another. To illustrate the strength of feeling, Kauffman, Ward and Badar (2016) show that parallels have been drawn between separate special education and discrimination against people because of their ethnicity or colour. Jordan and Goodey (2002) call segregated schooling 'educational apartheid' (p. 33) which denies children 'their humanity' (p.34), and Robertson (2015) calls specialist provision 'intrinsically discriminatory’ (p. 23). In contrast Hodkinson (2012) refers to inclusive education as a kind of 'conscience-salving simulacrum of social concern' (p. 6), and warns of the dangers of 'inclusion as spectacle', while Kauffman, Ward and Badar (2016) suggest that the theory behind full inclusion is 'delusion' (p. 72) and 'devoid of 
credible supporting evidence' (p. 73). For some (Hornby, 2015) it is not morally right to include all children in mainstream classrooms because it will mean that most will not receive an education which suits their needs, and Kaufmann and Hallahan (2005) suggest that inclusive education can mean that some children's education is sacrificed for the sake of misplaced ideology. Perhaps a more pragmatic summary of the oftenheated debate is Nussbaum's (2007) contention that a theory (in this instance, inclusive education) may be seriously great, yet have 'serious limitations in some area or areas' (p. 3.),

\section{Teachers' Attitudes and Understandings}

Teachers' beliefs are no more homogeneous (Gunnpórsdóttir, 2014), though it has been found that their notion of inclusion becomes clearer when they engage with the process (Booth et al, 2002). Avramidis and Norwich (2002) show that in the UK at least although teachers are generally positive about the general concept of inclusive education they do not share a total inclusion approach and hold differing views depending on their age, gender, and experience. Crucially to the position of this article, attitudes varied according to the perceived level of the disabling condition so that very few teachers were shown to be in favour of including young people with profound disabilities in mainstream settings. Loreman (2014) asked teachers in training in a postgraduate educational setting heavily committed to full inclusion if there were any groups who needed to be excluded from mainstream classrooms and why they should be excluded. Whereas one third supported inclusive classrooms, just over half justified exclusion for pupils with challenging behaviour and/or complex needs. Gunnpórsdóttir (2014) suggests that an ideological commitment to inclusive education might well be in direct relationship to the level of resources available, and that if these resources are not 
forthcoming, it may be perfectly natural for teachers to reject the idea of the moral rightness of inclusion especially with respect to learners with sld/pmld who usually require high levels of resources, specialised training, skills, experience, time and often medical support.

\section{Learner Perspectives}

In examining attitudes and beliefs, it is important of course to include the perceptions of the young people with sld/pmld themselves because if there were clear evidence of the attitudes of the leaners themselves to inclusion, then this would have a significant impact on the attitudes and beliefs of their teachers and other practitioners. Pupil voice is also central to UK Special Educational Needs and Disability Code of Practice (2015), with its first guiding principle being that parents and young people should be at the heart of the decision-making process. This presents major challenges for those trying to interpret the feelings and experiences of those on the sld and pmld spectrums (Fergusson et al, 2015), and is why they are frequently omitted from participatory research (Greathead et al: in print) and Watson et al (2006) warn of an over reliance on interpretation by parents and carers, especially where the children have little verbal communication.

Nevertheless, there have been a small number of research studies which have purported to highlight attitudes of learners with sld / pmld towards inclusion, although these studies can be compromised by inconsistency, the frontloading of data (Silberman, 2015), or problems of meaning and definition. Shogren et al (2015) for example undertook a study on the perspectives of students with disabilities on inclusive schools. Interviews were carried out with 86 students from six schools that were recognized as 
models of an inclusive school wide approach. According to the study, each school welcomed students with severe disabilities who participated in general education classrooms. However, the 'Interview Guide' (p. 247) advises the researchers to ask relatively complex questions such as 'How does your teacher help you learn?', and 'Do you ever interact with the Principal?', which suggest that the respondents could not have been classified as having sld/pmld according to any current definitions, and researchers admitted that inclusion of students with significant communication-related needs was a challenge and those who needed extensive communication support were not adequately represented in the sample.

Whitehurst (2007) conducted an arts project which aimed to gather the perspectives of children with profound and multiple learning difficulties on inclusion. However, as with Shogren et al (2015) the children selected for the project did not appear to fit any of the accepted definitions of pmld. The children had been 'selected to participate in the inclusion project on the basis of their ability to function well in new and challenging environments' (p. 57), and one of the young people was described as having 'moderate verbal skills and was always chatty and pleasant' (p. 59). It would be fair to ask in the case of these two research studies as well as in the case of Hudson, Browder and Wood (2013) discussed above the perspective and experiences of anyone with sld/pmld had been recorded at all.

\section{Inclusive classroom practice with respect to learners with sld/pmld}

Brantlinger (2006) notes that the ways we think about inclusive education will determine the ways we enact inclusive education, so it is important to explore whether 
the ambiguities around meaning we have discussed are reflected in school practice. At the same time, if there is rigorous evidence that inclusion in mainstream settings is meaningful and effective for those with sld/pmld then arguably ambiguities in debate and policy are less important.

It is difficult to find robust research that focusses on actual inclusive practice with respect to learners with sld/pmld in mainstream settings (Potter J, 2015 and Hornby, 2015). Access to this kind of research is compromised by the fact that without a universally agreed definition of sld / pmld or of inclusion judgements about what constitutes 'success' are likely to be compromised. In a comprehensive study of the literature around inclusive practices, Rix et al (2009) noted that the notion of 'success' was in general judged by the researcher, with teachers only involved in $38 \%$ of judgements and pupils in just 19\%. Avramides and Norwich (2002) point out that a limitation of observing practice may be that staff may alter their behaviour during the observation period to appear more inclusive in their approach, and Lacey and Scull (2015) have found that when observing teachers in fully inclusive settings in the UK, effective differentiation was problematic where schools do not employ sufficiently experienced and qualified specialist teachers, and teachers often claim to use differentiation more than they actually do. Lesson time can simply consist of keeping a learner with sld/pmld visibly busy with no real connection to the rest of the class. Lacey and Scull also observed instances of teachers not acknowledging the pupil's non-verbal vocalisations, or asking for the leaner to be taken out of the room so as not to disrupt the learning of his or her peers. Understandings amongst teachers were often confusing or potentially detrimental, and in one instance it was 'difficult to get across the message 
that inclusion is not about treating everyone the same but about identifying and mitigating individual learning barriers' (p. 1).

Cameron (2014) studied teacher/student interactions in 'inclusive classrooms' in Ohio. These classes purported to include children with severe disabilities, although teachers reported that children with severe difficulties were only included in mainstream classes for less than half of the school day. The teachers also described the routine handing over of responsibility for those with sld from teachers to 'paraprofessionals' with one class teacher describing the work of one child with sld as 'totally separate from what we are doing' (p. 270). Webster and Blatchford (2014) also observed that mainstream teachers regularly handed over responsibility for pupils with Statements of Special Educational Need to teaching assistants, who were insufficiently qualified, trained and experienced for the task. The issue of appropriate training is further underlined by Florian and Black-Hawkins (2011) who note that a common finding in international research literature is that teachers feel pupils with sld and pmld need specialist teaching which they have not been trained to provide, and Carter (2015) in his review of initial teacher training (ITT) in the UK, points to a significant gap in training courses with an SEN element.

Even in countries where full inclusion is government policy, the reality (Gunnpórsdóttir, 2014) is often far removed from policy decisions. Gunnpórsdóttir (2014) cites the example of Iceland where the implementation of an apparently highly inclusive system is meeting considerable resistance. Teachers are not satisfied with current arrangements and are struggling to handle the diversity of students in their schools. As a consequence, 
units or whole buildings now educate pupils within a parallel system of 'Internal Segregation' (ibid). This opposition to full inclusion is also reflected in Nord-Rhein Westphalen in Germany (Niemeyer, 2016) where full inclusion is recent policy. Data from the US (Shogren et al, 2015), also suggests that students with severe disabilities remain disproportionately less likely to access mainstream education classrooms.

It is perhaps not surprising then to find (Male and Rayner, 2007) that very few pupils with sld/pmld have been fully included in mainstream schools in the UK, with recent figures suggesting that only $27 \%$ of children with SLD and $18 \%$ of children with pmld are educated in mainstream schools, and Lacey and Scull (2015) giving an even smaller percentage $(22 \%)$ of pupils with sld in mainstream settings. There is also a very real concern (Lawson et al, 2015) that there are now many different types of school in the UK, some of which such as 'Free Schools' and 'Academies', which are no longer under local authority control, are not obliged to follow the National Curriculum and do not necessarily have to employ qualified teachers which brings with it, the author suggests, a danger of narrowing the provision for learners with sld/pmld even further.

The stark reality is that the inclusion of those with sld/pmld poses challenges in a mainstream environment (Whitehurst, 2007) no matter how committed the school is to the concept of full inclusion (Runswick-Cole, 2015). These children challenge schools, families and a wide range of community services, and they challenge the most skilled teachers (Carpenter, B et al, 2015). Differentiation within a whole class approach (Florian, 2007), or simply breaking down the curriculum into small steps (Male, 2015) is not enough. Children with sld / pmld do not simply require teaching at a slower pace 
(Porter and Ashdown, 2002) and as we have seen, mainstream type curricula which follow a linear, academic model are simply not appropriate (Imray and Hinchcliffe 2014 and Lacey and Scull, 2015) and it is the author's position that this conceptual mismatch between the ideal of full inclusion and the nature of the linear mainstream model the learners are usually invited to be a part of has led to them being largely overlooked in classroom practice.

\section{Special Schools}

This hasn't meant of course that the needs of children with sld/pmld have not been met. Largely overlooked or misrepresented in the inclusion debate, in the UK most have settled almost by default into special schools and we are now at a point in the UK (Rieser, 2016) where it is assumed those labelled with sld/pmld will attend special schools, and this is by far the most likely placement for them, especially as Attwood (2013) has shown if they require high levels of additional support such as breathing and feeding apparatus. The numbers tend to increase towards the end of primary school at age 11 and the beginning of the secondary stage, with pupils between the ages of 10 and 11 entering special schools at the beginning of the 2013/14 academic year increasing by nearly a third (MENCAP, 2014) and Head teachers estimating that the population of their schools is changing to include more pupils with sld/pmld (Calow, 2015). This may be because as Kaufmann, Ward and Badar (2016) point out, secondary schools are simply more complicated places than primary schools and full inclusion becomes problematic as children get older. In the majority of UK special schools, there is no doubt that all learners, including presumably those with sld/pmld are well provided for, respected and supported. After all, 92\% of England's special schools were rated as 
either good or outstanding in 2015 (38\% outstanding) with only 8\% requiring improvement (Ofsted, 2015). But does that mean we can rest on our laurels with respect to the 40,000 or so learners with sld/pmld in the UK and many more elsewhere?

\section{The need for a new conceptual framework}

Since the turn of this century, people with disabilities have continued to have poor life outcomes (Stobbs, 2017). People with sld/pmld are more likely to experience poverty or financial constraints (Bond, 2013), living circumstances and life events associated with an increased risk of mental and physical health problems (Goward et al. 2005; O'Brien, 2016), and are 'disproportionately vulnerable to violence and abuse' (Shakespeare, 2014 p. 96) with precipitating factors including poor social support, fewer friends, a lack of intimacy and social integration, isolation and exclusion (Bond, 2013). This would suggest that irrespective of the setting, young people with sld/pmld are perhaps still not leaving school with life chances which are appropriate to their needs and subjective being, or which support them and their carers to live lives which are just, dignified and of value. In fact, in the same way that there has been little agreement or clarity in the last half century about the meaning of inclusion with respect to learners with sld/pmld, so there has arguably been even less agreement about the goals of education for this group (Ware, 2017). As we have seen, pedagogies based on behaviourist approaches and linear academic curricula which prepare learners for autonomy and employment are problematic (ibid, p. 28; Author, 2017). These young people are not likely to be employed in any conventional sense or live 'independently', which means that curricula of the type favoured in the UK Special Education Needs and Disabilities Code of Practice (2015) based on 'high aspirations about employment, 
independent living and community participation' (SENCoP 8.7, p124) are unlikely to work in their favour.

If future policy is to include learners with sld and pmld we will clearly need to look for a new paradigm to challenge familiar models and ways of thinking about education. Certainly, a more flexible education system, or at the very least a significant restructuring of the school system, where the place of education should be less important than its content and quality (Lacey and Scull, 2015). Perhaps though what we actually need is a wider and more holistic approach where educational outcomes for people with sld and pmld will be dependent on the equal opportunities provided by the rest of society with a philosophical shift in thinking needed to redefine what constitutes a successful and inclusive democracy and therefore what constitutes an effective education as a preparation to live within that democracy.

The author agrees with Simmons and Watson (2014), Shakespeare (2014 and 2013) and Vehmas (2012) who all put forward the capabilities approach developed by Amartya Sen (1992) and Martha Nussbaum (2006) as a field of scholarship and a potential approach to educational provision that addresses many of the concerns discussed in this article. The strengths of the capabilities approach for exploring and reframing outcomes for those with sld/pmld are that it is pragmatic and normative focussing as it does on being and doing (Nussbaum, 2006) and on actual functioning and realistic opportunity as well as holistic outcomes and how to measure those outcomes. Nussbaum's capability approach asks difficult questions of direct relevance to educational provision in the $21^{\text {st }}$ century and Johnson and Walmsley go so far as to 'wonder what would 
happen if we took Nussbaum's capabilities list and made it the focus of our work with people with disabilities;' (p. 174).

\section{Conclusion}

Shakespeare (2014) has stated that people with learning difficulties may not have been problematized at all in a culture where literacy and intellectual knowledge were not prioritised, but as we have seen they have, and this has been the case and in particular with respect to learners with sld/pmld in both policy and practice. To date, curricula and educational outcomes for all have tended to be linear and academic, and educational policy and practice with respect to learners with sld/pmld have reflected this, with the result that this sizeable group of learners has been overlooked. The positioning of our most complex learners in our education systems must be one of the key drivers for a change in approach and a redefinition of inclusive education so that young people with sld/pmld can have school experiences which are appropriate to their lives, and enjoy outcomes which support and prepare them and their carers to live lives which are of inherent and lasting value.

\section{(7135 words)}




\title{
References
}

\begin{abstract}
Ainscow, M, (2005). Developing inclusive education systems: what are the levers for change? Journal of educational change, 6 (2), pp.109-124.
\end{abstract}

Aird, R (2001) The Education and Care of Children with Severe, Profound and Multiple Learning Difficulties. London: David Fulton Publishers

\begin{abstract}
Allan, J and Brown, S (2001) Special Schools and Inclusion, Educational review, 53 (2), 2001: pp.199-207
\end{abstract}

Allan, J. (2013). Inclusion: Patterns and possibilities. Zeitschrift für Inklusion, (4).

Available from: http://inklusion-online.net/index.php/inklusiononline/article/view/31/31 (Accessed 22 June 2016)

Armstrong, A. C., Armstrong, D. and Spandagou, I. (2010) Inclusive Education, London: Sage 
Armstrong, F (2016) Inclusive Education: School cultures, teaching and learning. In Richards G and Armstrong, F. (2016) Teaching and Learning in Diverse and Inclusive Classrooms. (Chapter 1) London: Routledge.

\begin{abstract}
Attwood, L. (2013). The real implications of 'benevolent' SEN reform. Support for Learning, 28(4): 181-187.
\end{abstract}

Author (2017)

Author (2013)

Avramides, E and Norwich, B (2002). Teachers' attitudes towards integration / inclusion: a review of the literature. European Journal of Special Needs Education. 17(2): $129-147$

Ayres, K M, Lowery K A, Douglas K H, and Sievers C. (2012). The Question Still Remains: What Happens when the Curricular Focus for Students with Severe Disabilities Shifts? A Reply to Courtade, Spooner, Browder, and Jimenez (2012). Education and Training in Autism and Developmental Disabilities, 2012, 47(1), 14-22 
Blatter J., Blaettler, A, Schmid S. (2015) What happened / s to inclusion? A plea and three proposals for closing the gap between democratic theory and Empirical measurement of democracies. Political Concepts - working paper series. University of Lucerne

Bond (2013) Children and Young People with learning disabilities - understanding their mental health. Available at http://www.youngminds.org.uk/assets/0000/9593/Children_and_Young_People_with_L earning_Disabilities_intro.pdf

Brantlinger, E. A. (Ed.). (2006). Who benefits from special education?: remediating (fixing) other people's children. Routledge.

Blower, C (2015) Inclusive Thinking. The Teacher Magazine. London: National Union of Teachers

Byers and Lawson (2015) Priorities, products and process - developments in providing a curriculum for learners with SLD/PMLD in Lacey P et al (eds) The Routledge Companion to severe profound and multiple learning difficulties, London Routledge. pp 38-47

Booth, T., Ainscow, M., Black-Hawkins, K., Vaughan, M., \& Shaw, L. (2002). Index for inclusion: Developing learning and participation in schools. Bristol: CSIE 
Calow. L (16 November, 2015). 'The Head Teacher's Story’ Lecture to Undergraduate Students. London: University of East London.

\begin{abstract}
Cameron, D.L., (2014). An examination of teacher-student interactions in inclusive classrooms: teacher interviews and classroom observations. Journal of Research in Special Educational Needs, 14(4): 264-273.
\end{abstract}
Carpenter B et al. (2015), Engaging Learners with complex learning difficulties and disabilities. A resource book for teachers and teaching assistants. London: Routledge.

Carter, A. (2015). Carter review of initial teacher training Dept. for Education.

Dahl, R. A. (1991). Democracy and its Critics. Yale University Press.

Dept for Education and Skills (2007) 'Aiming High for Disabled Children' London: HMSO 
Department for Education and Skills. (2004). Removing Barriers to Achievement:

The Government's Strategy for SEN. London: Department for Education and Skills.

DfE (2012) Glossary of special educational needs (SEN) terminology.

http://webarchive.nationalarchives.gov.uk/20130123124929/http://www.education.gov. uk/a0013104/glossary-of-special-educational-needs-sen-terminology [Accessed 8th December 2017].

\begin{abstract}
Department for Education (2011) Support and Aspiration: a new approach to special educational needs and disability, London: Department for Education
\end{abstract}

DfE (2014) Performance - P Scale - attainment targets for pupils with special educational needs. https://www.gov.uk/.../p-scales-attainment-targets-for-pupilswithsen [Accessed July 22 $\left.2^{\text {nd }} 2016\right]$.

Department for Education / Department for Health (2014) Special Educational Needs and Disability Code of Practice: 0 - 25 years, London: Department for Education

Department of Health (2010): Valuing People Now. London: DoH

Department of Health (2001): Valuing People. London: DoH 
Dyson, A., (1999) Inclusion and inclusions: theories and discourses in inclusive education. World yearbook of education 1999: Inclusive education, pp.36-51.

Fergusson, A, Howley, M, Rose, R and Allen, R. (2015) Hidden Behind a label: an uneasy relationship between mental health and special needs, in Lacey P et al (eds) The Routledge Companion to severe profound and multiple learning difficulties, London Routledge, pp 201-211

Florian, L. (2010) Special Education in an era of inclusion: the end of special education or a new beginning? The Psychology of Education Review. 34 (2): 22-29

Frogley, G and Welch J. (1993) A Pictorial History of Netherne Hospital. Redhill: East Surrey Area Health Authority.

Gillard D (2009) Us and them: a history of pupil grouping policies in England's schools. Forum 51(1) 49-72.

Goodey, C. (2011) A history of intelligence and intellectual disability: the shaping of psychology in early modern Europe. Farnham, UK: Ashgate 
1

2

3

4

5

6

7

8

9

10

Goward, P, et al. (2005) Learning disability: a life cycle approach to valuing people. McGraw-Hill International.

Greathead S, Yates R, Hill V, Croydon A, Kenny L and Pellicano E. (in print) Supporting children with limited language to make their views known: A mixed methods study.

Grove, N. (2012) Story, Agency, and Meaning Making: Narrative Models and the Social Inclusion of People with Severe and Profound Intellectual Disabilities. Journal of Religion, Disability \& Health, 16(4): 334-351.

Gunnpórsdóttir, H. (2014) The teacher in an inclusive school: exploring teachers' construction of their meaning and knowledge relating to their concepts and understanding of inclusive education. Dissertation submitted in partial fulfilment of a Ph.D.degree. University of Iceland, School of Education.

Hart S and Drummond M (2014) Learning Without Limits: Constructing a Pedagogy Free From Determinist Beliefs about Ability in L Florian (ed, 2nd ed) The Sage Handbook of Special Education. London. Sage

Hodkinson, A. (2012) Illusionary Inclusion. What went wrong with New Labour's landmark educational policy? British Journal of Special Education. 39 (1): 4 - 10 
Hornby, G. (2015) Inclusive Special Education: development of a new theory for the education of children with special educational needs and disabilities. British Journal of Special Education. 42 (3): 234-256, London: NASEN.

Howes, A, Davies, S, and Fox S. (2009) Improving the context for inclusion:

Personalising teacher development through Collaborative Action Research. London and New York: Routledge

Hudson, M. E., Browder, D. M., \& Wood, L. A. (2013). Review of experimental research on academic learning by students with moderate and severe intellectual disability in general education. Research and Practice for Persons with Severe Disabilities, 38, 17-29.

Imray P and Hinchcliffe V (2014) Curricula for Teaching Children and Young People with Severe or Profound Learning Difficulties. London. Routledge.

Jay, M (2016) This Way Madness Lies: The Asylum and Beyond. London: Thames and Hudson

Jordan, L and Goodey, C. (2002) Human Rights and School Closure - the Newham Story. Bristol: CSIE 
Kauffman, J, Ward, D and Badar, J. (2016) The Delusion of Full Inclusion, in Foxx R and Mulick, J (eds) Controversial Therapies for Autism and Intellectual

Disabilities. New York: Routledge, pp. 71-84

Kaufmann, J and Hallahan, D. (eds.) (2005). The illusion of full inclusion: a comprehensive critique of the current special education bandwagon (second edition) Austin, TX: PRO-ED

Kearney, A (2011) Exclusion From and Within School. Rotterdam: Sense Publishers Kittay, E (2011) The Ethics of Care, Dependence and Disability, Ratio Juris. Vol. 24 No. 1 March 2011 (49-58)

Lacey, P. (2001) The role of learning support assistants in the inclusive learning of pupils with severe and profound learning difficulties. Educational Review, 53(2): 157167.

Lacey, P. (2011) Educational Provision for Pupils with Severe and Profound and Multiple Learning Difficulties. Unpublished Report, Birmingham: MENCAP / University of Birmingham

Lacey P et al, (eds.) (2015) The Routledge Companion to severe profound and multiple learning difficulties. Routledge, London. 
Lacey, P. and Scull, J., (2015) Inclusive Education for Learners with Severe, Profound and Multiple Learning Difficulties in England. Including Learners with LowIncidence Disabilities, 5, pp.241-268.

Lawson et al. (2015) Curriculum models, issues and tensions, in Lacey P et al (eds) The Routledge Companion to severe profound and multiple learning difficulties, London Routledge (pp 233-245)

Loreman T, Deppeler J and Harvey D (2010) Inclusive education: Supporting diversity in the classroom. Abingdon. Routledge.

Male, D. (2015) Learners with SLD and PMLD: provision, policy and practice, in Lacey $\mathrm{P}$ et al (eds) The Routledge Companion to severe profound and multiple learning difficulties, London Routledge, pp 9 - 18

Male D and Rayner M (2007) Who Goes to SLD Schools? Aspects of policy and provision for pupils with profound and multiple learning difficulties who attend special schools in England. Support for Learning, 2007, Vol.22(3), p.145-152 
McRuer (2008) Crip Eye for the Normate Guy: Queer Theory and the Disciplining of

Disability Studies. PMLA, Vol. 120, No. 2 (Mar., 2005), pp. 586-592 Published by:

Modern Language Association

MENCAP. (2014) Parents: mainstream schools are failing our children with a learning disability [online]. Available from:

https://www.mencap.org.uk/news/article/parents-mainstream-schools-arefailingour-children-learning-disability (accessed 5th December 2015).

Murray, M. (2015) Teachers morale has never been lower. The Independent

Newspaper. Monday April $27^{\text {th }} 2015$ p. 32

Newham Council (1995). Review of Inclusive Education Strategy: Consultation Document

NCC (National Curriculum Council) (1989) Curriculum Guidance 2 - a Curriculum for All: special educational needs in the national Curriculum, York: NCC

Niemeyer, M. (2014) The Right to Inclusive Education in Germany. The Irish Community Development Law Journal. 3 (1).

Norwich, B. (2008) Dilemmas of difference, inclusion and disability: international perspectives on placement. European Journal of Special Needs Education, 23(4): 
287-304.

Nussbaum, M. (2007) Frontiers of Justice - Disability, Nationality, Species

Membership. Harvard University Press

O'Brien J (2016) Don't send him in tomorrow. Shining a light on the marginalised, disenfranchised and forgotten children of today's schools. Carmarthen. Independent Thinking Press

Ofsted (2006) Inclusion: Does it matter where pupils are taught? HMI 2535

Pather, S. (2007) Demystifying Inclusion: implications for sustainable inclusive practice. International Journal of Inclusive Education. 1 (17)

Polat, F. (2011) Inclusion in education: A step towards social justice. International Journal of Educational Development, 31(1): 50-58.

Porter J and Ashdown R. (2002) Pupils with complex learning difficulties: promoting learning using visual materials and methods, London: David Fulton / NASEN

Potter. (2015) Engaging with Research, in Lacey P et al The Routledge Companion to severe profound and multiple learning difficulties, London Routledge, pp 399-410 
QCA (2009) The P Scales. Level descriptors P1 to P8. London. Qualification and Curriculum Authority.

QCA (Qualifications and Curriculum Authority) / DfEE (Department for Education and Employment) (2001) Planning, teaching and assessing the Curriculum for Pupils with Learning Difficulties, London: QCA.

Richards G and Armstrong, F. (2016) Teaching and Learning in Diverse and Inclusive Classrooms. London: Routledge.

Rieser, R. (2016) Global Approaches, in Richards G and Armstrong, F. (2016) Teaching and Learning in Diverse and Inclusive Classrooms. London: Routledge

Rix, J., Hall, K., Nind, M., Sheehy, K. and Wearmouth, J. (2009) What pedagogical approaches can effectively include children with special educational needs in mainstream classrooms? A systematic literature review. Support for learning, 24(2): 86-94.

Robertson, C. (2015) Changing special educational needs and disability legislation and policy. Implications for learners with SLD/PMLD, in Lacey P et al (eds) The Routledge Companion to severe profound and multiple learning difficulties, London Routledge: pp 19-28. 
Runswick-Cole, K. (2011) Time to end the bias towards inclusion. British Journal of Special Education. 38 (3): 112-119

Shakespeare, T (2014) Disability Rights and Wrongs (2nd Edition). London: Routledge

Shakespeare, T (2013) Nasty, Brutish and Short in J Bickenback, F Feder and B Schmitz (eds) Disability and the Good Human Life, Cambridge: Cambridge University Press

Shogren, K. A., Gross, J. M., Forber-Pratt, A. J., Francis, G. L., Satter, A. L., BlueBanning, M., \& Hill, C. (2015) The perspectives of students with and without disabilities on inclusive schools. Research and Practice for Persons with Severe Disabilities, 2015. 40: 173-1

Shuttleworth, M. A. (2013) Inclusion is...: Musing and Conversations about the Meaning of Inclusion. Youth: Responding to Lives (pp. 109-121). SensePublishers.

Silberman, S. (2015) Neurotribes: The legacy of autism and the future of neurodiversity. London: Penguin.

Simmons B and Watson B (2014) The PMLD Ambiguity. London: Karnak Books Limited 
Stewart, D. (2015) An historical reflection on education for learners with SLD/PMLD 1800-1970, in Lacey et al (eds.) The Routledge Companion to severe profound and multiple learning difficulties, London: Routledge, pp 29-37

Stobbs, P (2017) We're all in it together - aspirations and legislation in a time of austerity: British Educational Research Association Special Interest Group, University of East London 15th July 2017

Taylor B (2014) The Last Asylum - a memoir of madness in our times. London. Penguin Unesco. (1994) The Salamanca Statement and Framework for action on special needs education: adopted by the World Conference on Special Needs Education; Access and Quality. Salamanca, Spain, 7-10 June 1994. Unesco.

United Nations (1948) Universal Declaration of Human Rights. New York: United Nations

United Nations (1989) Convention on the Rights of the Child (New York: United Nations

Vehmas S (2012) What can philosophy tell us about disability? In Watson N et al (eds) (2014) Routledge Handbook of Disability Studies London: Routledge (pp 298-309) 
Walton, E (2016). The Language of Inclusive Education. London: Routledge

\author{
Ware, J. 2017, 'Assessment for learners with PMLD', BERA Annual Conference Sept \\ $5^{\text {th }} 2017$
}

Ware J (2014) Curriculum Considerations in Meeting the Educational Needs of Learners with Severe Intellectual Disabilities in L Florian (ed, 2nd ed) The Sage Handbook of Special Education. London. Sage.

Warnock, M (1975). Report of the Committee of Enquiry into the education of handicapped children. London: HMSO

\begin{abstract}
Warnock, M. (2005) Special Educational Needs: A New Look. V L. Terzi (Ur.). Special educational needs: a new look, pp.11-46.
\end{abstract}
Watson, Abbott and Townsley. (2006) Listen to me too! Lessons from involving children with complex healthcare needs in research about multi-agency services. Child care, health and development, Vol 33, 1, pp 90-95

Wearmouth J. (2011) Special Educational Needs - the basics. London: Routledge. 
Webster, R and Blatchford P. (2014) Who has the responsibility for teaching pupils with SEN in mainstream primary schools? Implications for policy arising from The 'Making a Statement' study. Journal of Research in Special Educational Needs · 14 (3): 196200

Wehmeyer, M. L. (Ed.). (2013). The story of intellectual disability. Baltimore, MD: Paul H. Brookes

Wehmeyer, M. L. (2006). Beyond access: Ensuring progress in the general education curriculum for students with severe disabilities. Research and Practice for Persons with Severe Disabilities, 31(4), 322-326.

Westwood P. (2015), Common-sense Methods for Children with Special Educational Needs, Routledge, London

Whitehurst, T. (2007) Liberating Silent Voices - perspectives of children with profound and complex learning needs on inclusion. British Journal of Learning Disabilities 35: 55-61 London: Blackwell 